\title{
Social-ecological transformations of Inner Mongolia: a sustainability perspective
}

\author{
GuangHua $\mathrm{Xu}^{1,2^{*}}$ and JianGuo $\mathrm{Wu}^{3,4}$
}

\begin{abstract}
Introduction: Sustainability requires the reconciling of human needs with the healthy natural ecosystem, which should be achieved within the grand course of industrialization and modernization. Systematic transitions on demography, economy, technology, and institutions are required, while different civilizations may take their respective paths. In this study, we analyze the social-ecological transitions of Inner Mongolia Autonomous Region of China during the past century, focusing on major changes in its environmental, demographic, and socioeconomic conditions.

Results: A two-level social-ecological system analysis framework was proposed, and four stages of transition were identified: traditional nomadism, primitive industrial civilization, collectivization era, and economic reform/opendoor policy era. Our analysis showed that Inner Mongolia has made great achievements in its socioeconomic domains but is faced with numerous challenging environmental problems. Overconsumption of resources and failure to curtail ecological degradation may lead to a trap of unsustainability.

Conclusions: However, the slowing-down population growth, improvements of the economic structure, and many new sustainability initiatives and strong support from the central government together give hope for a sustainable future of the region.
\end{abstract}

Keywords: Sustainability transition, Inner Mongolia, Social-ecological system, Demographic transition, Modernization, Ecological trap

\section{Introduction}

Industrialization and associated technological advances have greatly increased the world's population and affluence, significantly altered global ecosystems and landscapes, and brought myriad environmental problems such as resource shortage, biodiversity loss, and climate change (Steffen et al. 2005). For the sustainability of our civilization, human demands must be reconciled with the earth's service supply capacity, necessitating a global sustainability transition (Clark 2001; Kates et al. 2001; National Research Council 1999; Parris and Kates 2003; Raskin et al. 2002; Reid et al. 2010; Schellnhuber et al. 2011; Weinstein et al. 2013). Social-ecological systems are complex adaptive systems with internal feedbacks

\footnotetext{
* Correspondence: guanghuaxu@zafu.edu.cn

${ }^{1}$ School of Forestry and Bio-technology, Zhejiang A\&F University, Lin'an,

Zhejiang 311300, China

${ }^{2}$ Centre for China-Africa Agriculture and Forestry Research (CAFOR), Zhejiang

A\&F University, Lin'an, Zhejiang 311300, China

Full list of author information is available at the end of the article
}

and nonlinear dynamics, but current policies and norms, based mainly on command and control, often focus on the symptoms rather than underlying causes of unsustainability (Weinstein et al. 2013; Garmestani 2014; Holling and Meffe 1996). To increase the chance of success in sustainable transformations, it is important to examine past evolving trajectories, identify key variables and their interactions, and understand how they result in fundamental structural changes (Chapin et al. 2006; Olsson et al. 2014; Reid et al. 2010; Scheffer and Westley 2007).

From a historical point of view, human civilization is in the grand course of transition from traditional agricultural civilization to industrial and post-industrial civilizations (Boserup 1981; Cumming et al. 2014; Zeder 2008). Ancient civilizations like hunting and gathering or farming rarely ran into problems of environmental disruption, because of their limited technical capability, as well as rules and traditions that they developed to maintain their own resource bases. It is the greatly 
advanced technology and industrial power, combined with the rapidly increasing population and its everexpanding demands for resources, that has pushed the world onto an unsustainable trajectory. However, the dynamics of complex social-ecological systems are forever irreversible and unpredictable (Holling 1973, 2001; $\mathrm{Wu}$ and $\mathrm{Wu}$ 2013). For human society to return back to the ancient state is impossible and unreasonable. Sustainability of our civilization needs to be achieved within the modernized world and coexists harmoniously with it (van den Bergh 2011).

Social-ecological transition happens when gradual or abrupt changes of external or/and internal conditions drive the system away from its initial dynamic steady state, during which the system undergoes structural changes until new feedback mechanisms are created to regain its stability (Chappin and Ligtvoet 2014; Holling 1973, 2001; Meadowcroft 2011; Rotmans et al. 2001; Scheffer et al. 2001; van den Bergh et al. 2011). The US National Research Council (NRC) addressed the goal of sustainability transition as "a stabilizing world population meets its needs and reduces hunger and poverty while maintaining the planet's life support systems and living resources" (National Research Council 1999). Towards this end, several fundamental and systemic shifts are required on the global level (Crossman et al. 2013; Gell-Mann 2010; Kates and Parris 2003), including (1) a demographic transition to low population growth rates (Caldwell et al. 2006; Notestein 1983); (2) an economic transition eliminating poverty and hunger and switching to high-level needs that are less harmful to the environment; and (3) technological and institutional transitions which allow the demographic and economic transitions to happen while protecting the environment. Thus, the human-nature relationship would outgrow the hostile stage of "conquering nature" as reflected in the philosophical and political ideologies, through cooperative coevolution and integrated landscape planning and management (Farina 2000; Naveh 2000, 2005). New equilibrium between human well-being and ecosystem integrity at global scale may be achieved, which would provide a solid foundation for sustainability (Wu 2013).

Such a transition will not be a smooth sailing. Cumming et al. (2014) provided a conceptual model of agricultural transitions, showing that the interacting processes of technological change, population growth, and urbanization may over-exploit ecosystems leading to "green" or "red" traps. A "green trap" takes place when positive feedback reinforce rural poverty and ecological degradation, while a "red trap" happens because of overconsumption and failure to maintain the integrity of ecosystems. Between these two poles of green and red traps, a continuum of combinations could be possible (Fig. 1).
Neither the developed world nor the developing world is on a path to the ultimate sustainability. Developed countries have achieved a greater success in the grand sustainability transition, but their overconsumption has contributed significantly to the world's unsustainability, usually through uneven exchanges with developing countries (Hornborg 2014). Promoting the sustainability transition in developing countries-which hold the majority of the world's population-is particularly urgent if we are to achieve global sustainability in decades to come. Studies that examine the historical transition courses in developing countries are helpful for improving our understanding and practice of sustainable development in these regions.

As the world's largest developing country, China is inhibited with roughly $20 \%$ of the world's total population, and its development is of great importance to the world's sustainability transition. Inner Mongolia is the largest pastoral area of China and also has high indigenous species diversity in its many unique landscapes (Wu et al. 2015) which has experienced multiple political regime shifts, as well as substantial changes in environmental and socioeconomic conditions during the past century (Jiang et al. 2006; Tong et al. 2004). In this study, we aimed to achieve two main objectives: (1) to examine the historical transitions of Inner Mongolia as a social-ecological system during the past century, with an emphasis on the coevolving relationship between human and nature, and (2) to assess whether Inner Mongolia has been on a path of sustainability transition based on a historical and social-ecological analysis.

\section{Methods}

Study area

Inner Mongolia is located in North China, stretching over more than $2000 \mathrm{~km}$ from east to west and covering a total area of 1.18 million $\mathrm{km}^{2}$ (Fig. 2). The high latitude and altitude, as well as its distance from the ocean, result in a temperate continental monsoon dominated climate. With an average annual temperature around -2 to $6{ }^{\circ} \mathrm{C}$, the winter is long and cold, while the summer short and hot. Annual precipitation is $50-450 \mathrm{~mm}$, decreasing from east to west, and concurrently appears with temperature peak, which favors vegetation growth. Evaporation is above $1200 \mathrm{~mm}$ in most parts of the region, much higher than precipitation (Shi 1982; Wu et al. 2015).

About $67 \%$ of the territory $\left(0.87\right.$ million $\left.\mathrm{km}^{2}\right)$ is covered by natural grasslands (steppes); besides that, there are also 0.19 million $\mathrm{km}^{2}$ forests and 0.07 million $\mathrm{km}^{2}$ of cultivated land (Han et al. 2009; Kang et al. 2007; Li 1962, 1979; Wu and Loucks 1992; Wu et al. 2015). However, humus covers only $30-50 \mathrm{~cm}$ in most areas under the grassland, while the rest is broadly distributed sand, deficient in organic matter and mineral nutrients (Shi 


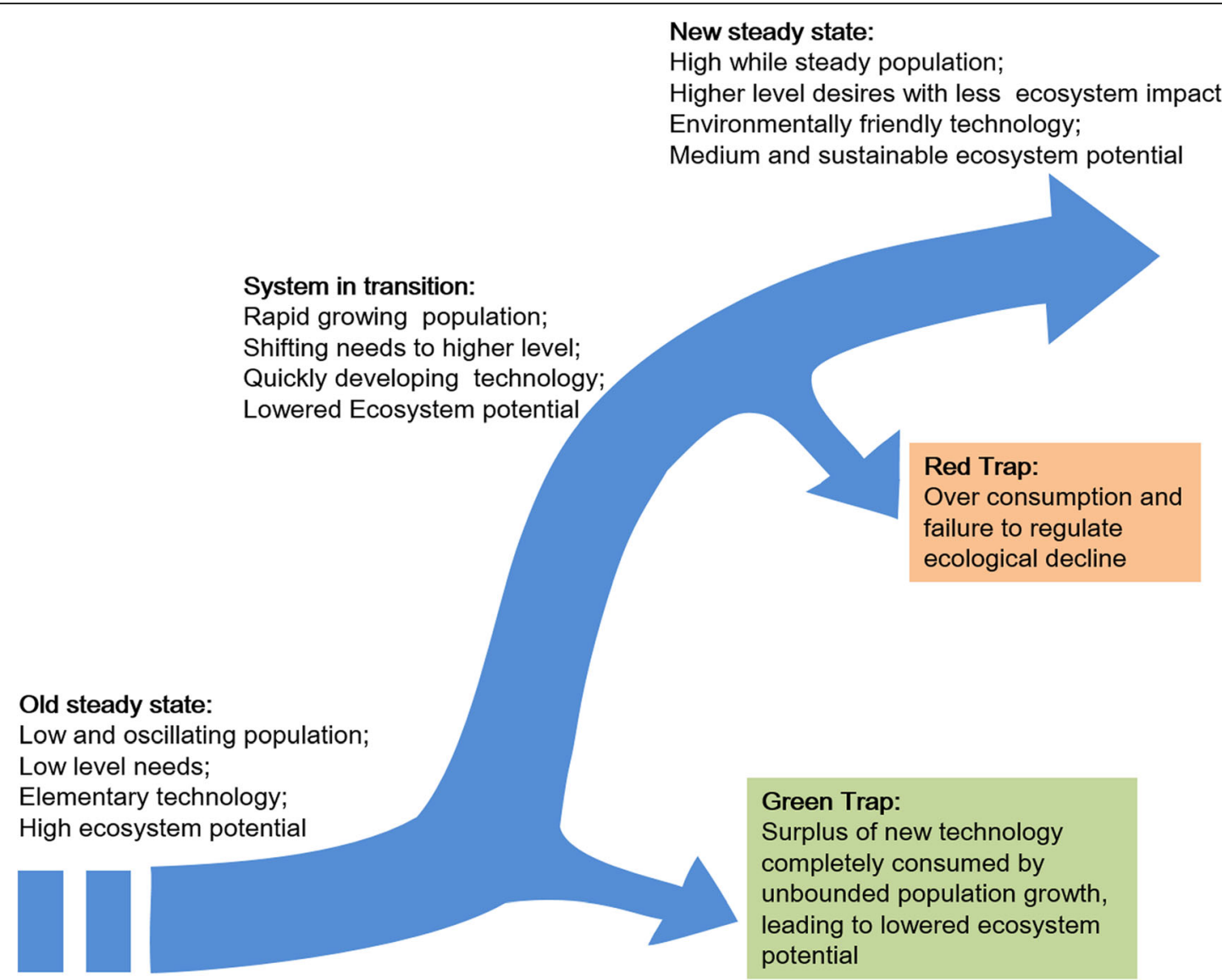

Fig. 1 Illustration of the course of grand sustainability transition. Human civilization shifts from the low-level subsistence sustainability to the high-level ultimate sustainability, with possible green and red traps of unsustainability as addressed in Cumming et al. (2014)

1982). The interdependence between organisms and environment forms a fragile balance, which is easily destroyable but hardly recoverable.

\section{Analytical framework}

For describing the evolution of complex social-ecological systems, narrative approaches with theoretical frameworks are usually adopted (Cumming et al. 2014; Grin et al. 2010; Markard and Truffer 2008; Smith et al. 2010). Here, we developed a two-level framework modified from a multi-level perspective (Geels 2002, 2011) to describe the historical transitions of Inner Mongolia, focusing on the interactions between human and nature.

The local natural resources and ecosystems provide services (or disservices) to the society, which were made available (or alleviated) through the production activities of the people. Production activities could be divided into industry, livestock husbandry, farming, etc., which are characterized by land use, engaged population, and produced value. Along with the production activities, population is also reproduced. Up above the production level, there are related institutional arrangements, including property rights and allocation rules/regulations of resources and products, as well as the social consciousness subsystem that reflects the knowledge level and value judgment of stakeholders. Besides that, the regional social system is also strongly influenced by extrinsic factors like immigration, economic/technological innovations, and national policies (Fig. 3).

\section{Results}

We describe the historical transformations of Inner Mongolia in two different while complementary steps, i.e., a four-stage narrative of the social-ecological system, followed with an analyzing of three key variables of the Inner Mongolia (ecosystem condition, population, and economy) to provide more thorough understanding of the transition.

\section{Different evolving stages of Inner Mongolia}

The division of the four stages is based mainly on the institutional changes of the social system. Within a stage, the main feedback relationships among key variables of Inner Mongolia remained the same or similar, although 


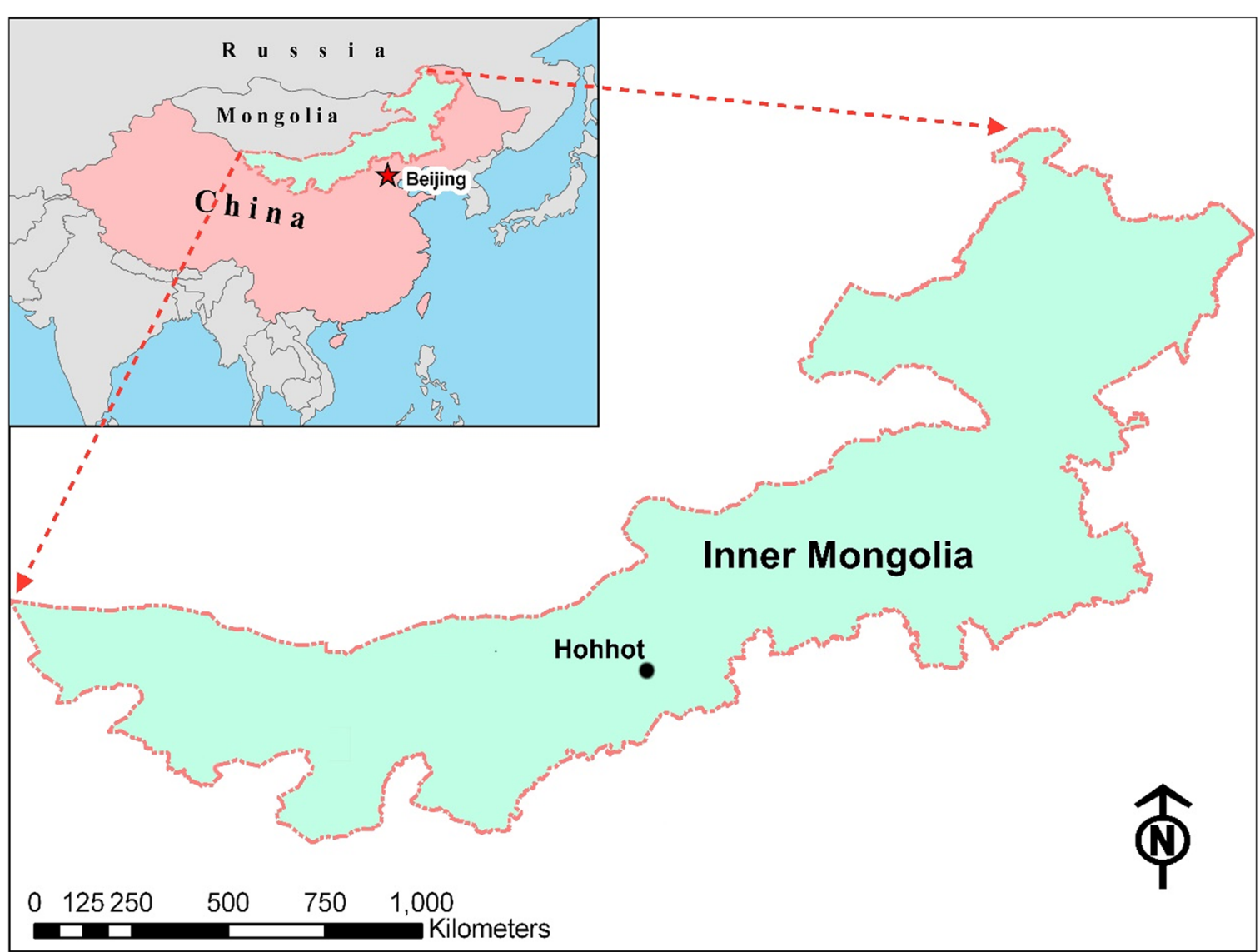

Fig. 2 Location of Inner Mongolia (modified from Wu et al. (2015)

gradual changes of some variables are possible. Between stages, however, qualitative transformation happens (Walker et al. 2004), which usually are the results of within-system processes and external influences from a broader scale (Table 1). A more detailed description of historical landscape dynamics and driving forces of Inner Mongolia is found in Wu et al. 2015.

\section{Traditional nomadism (before the 1900s)}

In the vast arid and semiarid regions of the Mongolian Plateau, harsh natural conditions could barely support large-scale farming systems, and a nomadic lifestyle became the choice of history (Bao 2005; Tian and Ma 2008). This land use form made good use of the mobility and feeding habits of herbivores to suit the changing dryland environment, converting the primary productivity of grassland into meat, milk, fur, and other necessities (Wang 2008; Xi 2010). Through moving around broad areas seasonally and annually, livestock had diverse forages, saline and mineral supplements, and a reduced risk of spreading diseases, while grasslands were fertilized relatively evenly with livestock manure (Bao 2015). As a way of human adaption to the natural environment, the nomadic land use reconciled the relationship between people, livestock, forage, and pasture, resulting in a culture that includes its unique production style, social system, and customs, for example, the selection of appropriate breeds, suitable grazing stations and nomadic routes, and social cooperative organizations to resist natural disasters (Liu 2005). In addition, people also created political organizations and paramilitary system (Uretogtohu 2006). Such technological measures and institutional arrangements enhanced adaptability, which maintained the relative stability of the grass-livestockherder system for over 2000 years (Wang 2006; Wu et al. 2015).

However, the nomadic economy was also fragile $\mathrm{CH}$ 2002; Lu 2005), and wealth accumulation and population growth were very slow (Jia 2011; Shen 1986). The military advantages of nomadic economy enabled it to partly compensate for its vulnerability through plundering adjacent agricultural societies, which was indeed a main theme of the ancient history of China (Barfield 1989; Lattimore 1988; Tian and Ma 2008). 


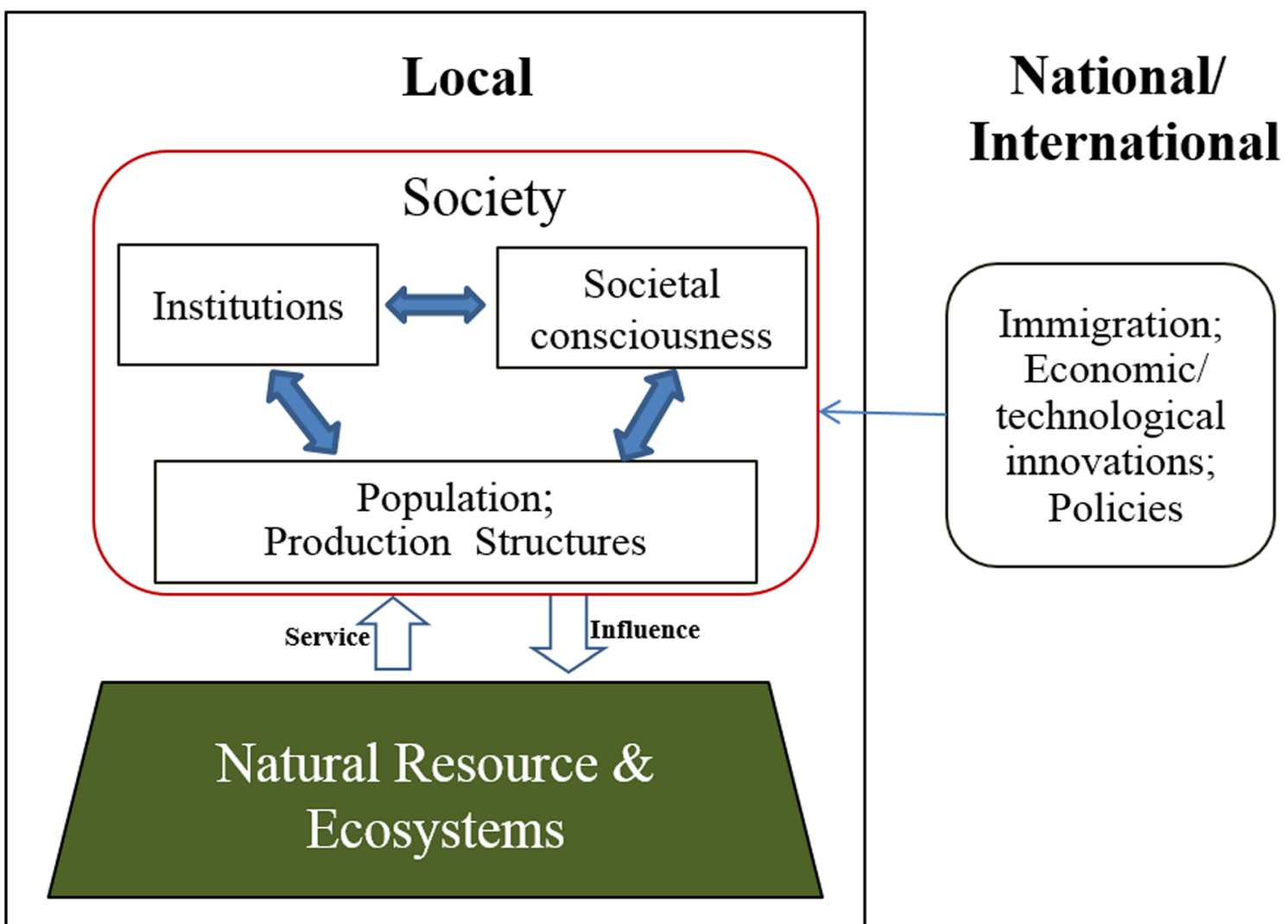

Fig. 3 Illustration of the analysis framework for Inner Mongolia as a social-ecological system

\section{Primitive industrial civilization (1900s-1949)}

In the beginning of the twentieth century, when industrial civilization dominated the western world, China was in a chaotic state characterized by repeated invasions and exploitation by imperialist countries, endless military conflicts between warlords, and a lack of governmental control. The long-term dominance of nomadic pastoralism in sInner Mongolia was also challenged by episodic but large-scale grassland-tofarmland conversion events in the last decades of the Qing Dynasty and during the era of the Republic of China (Wu et al. 2015). A key driver for such land

Table 1 Summary of different evolving stages of Inner Mongolia as a social-ecological system and their major characteristics

\begin{tabular}{|c|c|c|c|c|}
\hline \multirow{2}{*}{$\begin{array}{l}\text { Major } \\
\text { characteristics }\end{array}$} & \multicolumn{4}{|l|}{ Evolving stages } \\
\hline & $\begin{array}{l}\text { Traditional nomadism } \\
\text { (before the 1900s) }\end{array}$ & $\begin{array}{l}\text { Primitive industrialization } \\
\text { (1900s-1949) }\end{array}$ & $\begin{array}{l}\text { Collectivization } \\
(1949-1978)\end{array}$ & $\begin{array}{l}\text { Economic reform } \\
\text { (1978-present) }\end{array}$ \\
\hline $\begin{array}{l}\text { Natural resource } \\
\text { and ecosystems }\end{array}$ & Natural grasslands & $\begin{array}{l}\text { Localized cultivation and } \\
\text { land degradation }\end{array}$ & $\begin{array}{l}\text { Large-scale cultivation and } \\
\text { increasing land degradation }\end{array}$ & $\begin{array}{l}\text { Serious degradation due to } \\
\text { overgrazing, cultivation, mining, etc. }\end{array}$ \\
\hline $\begin{array}{l}\text { Production } \\
\text { structure }\end{array}$ & Primitive nomadism & $\begin{array}{l}\text { Traditional nomadism, with } \\
\text { limited sedentary pastoralism } \\
\text { and cultivation }\end{array}$ & $\begin{array}{l}\text { Sedentary pastoralism, with } \\
\text { increasing cultivation }\end{array}$ & $\begin{array}{l}\text { Privatized sedentary pastoralism, } \\
\text { with cultivation, mining, tourism, etc. }\end{array}$ \\
\hline Population & $\begin{array}{l}\text { Very low and sparsely } \\
\text { distributed }\end{array}$ & Episodic immigration waves & $\begin{array}{l}\text { Rapid growth, large-scale } \\
\text { immigration }\end{array}$ & $\begin{array}{l}\text { Steadily increasing, with low } \\
\text { immigration rate }\end{array}$ \\
\hline Institution & $\begin{array}{l}\text { Tribes, clans, and } \\
\text { feudalistic empires }\end{array}$ & $\begin{array}{l}\text { Tribes, subordination to } \\
\text { centralized government }\end{array}$ & Communes, collectivism & $\begin{array}{l}\text { Privatization, property rights, } \\
\text { marketization }\end{array}$ \\
\hline $\begin{array}{l}\text { Social } \\
\text { consciousness }\end{array}$ & $\begin{array}{l}\text { Reverence for nature, lamaism } \\
\text { (since 16th century) }\end{array}$ & $\begin{array}{l}\text { Lamaism and various other } \\
\text { trends of thought }\end{array}$ & Socialism, conquering nature & $\begin{array}{l}\text { Mixture of nature exploitation for } \\
\text { profits and nature conservation for } \\
\text { sustainability }\end{array}$ \\
\hline $\begin{array}{l}\text { National/ } \\
\text { international } \\
\text { influence }\end{array}$ & War, commercial trading & Immigration, capital & $\begin{array}{l}\text { Immigration, technology, } \\
\text { land use policy }\end{array}$ & Land use policy, common markets \\
\hline
\end{tabular}


conversion was the enormous pressure put on China by imperialist aggressions, which further impacted the pastoral areas of Inner Mongolia (Lattimore 1988). Large areas of natural grasslands were converted to farmland because of governmental policies for reclamation in order to pay for foreign indemnities or because of the lawless behavior of warlords often in the name of feeding their armies to resist imperialist aggressions (Lattimore 1988; Wu et al. 2015). Also, the Japanese imperialist turned vast areas of natural grasslands into farmland and looted a great deal of natural resources from Inner Mongolia to support their military aggressions against China and humanity (An 1995).

Warlords, local landlords, and foreign powers exploited the grasslands and the local herdsmen, devastating the socioeconomic development of the region (Da and Zheng 2010). Meanwhile, massive hungry inland farmers entered the grassland area to seek a new livelihood. Areas with best natural conditions and vegetation were converted into farmland, forming an expanding pastoral-agricultural transitional zone (Yan 2004). Farming in drylands of Inner Mongolia where precipitation is quite limited often led to the loss of soil fertility and consequently land degradation. The traditional nomadic pastoralism could no longer sustain itself under such conditions, and many herders had to settle down. When the People's Republic of China was founded in 1949, the sedentary herders reached $50 \%$ of the total pastoral population (Historiography Committee of Inner Mongolia Animal Husbandry Department 2000).

\section{The collectivization era (1949-1978)}

The newly established People's Republic of China adopted the socialistic system to achieve industrialization. Livestock herding in Inner Mongolia was incorporated into pastoral communes through the process of collectivization. Individual herdsmen were transferred into members of the people's commune who own the grassland, herds, and other production tools ( $\mathrm{Da}$ and Zheng 2010). Pastoral and agricultural products were produced at low costs, and a gradual modernization of animal husbandry took place. During this period, there were frequent reciprocal socioeconomic interactions between Inner Mongolia and inland China.

The nomadic mode of production underwent a series of changes, including specialization, sedentarization, and the introduction of new technologies, which improved the productivity of both animal and people. Sedentarization facilitated government service delivery, such as postal services, business services, education, and health care, which greatly improved the resilience of the herding community (Wang 2006). By 1965, traditional nomadism was largely abandoned (Xu 1999). Then, a pastoral system based on seasonal rotational grazing within a production unit was formed (Wang 2006, 2013). Meanwhile, the introduction of machinery like harvesters and wind generators, as well as breeding stations, greatly promoted the efficiency of animal husbandry (Lin and Zheng 1990). The efficiency of livestock raising was high, while its impacts on the environment were relatively low.

As the further expanding of animal husbandry, the grassland began to feel the pressure exerted by the rapidly increasing livestock and human populations. In particular, higher birth rate and lower mortality rate, plus increasing immigration influx, resulted in fast increasing human population (except the period 1960-1962). To feed the nationally growing population, the government expanded cultivated in several grassland areas across Inner Mongolia, substantially altered the structure and function of Inner Mongolia as a social-ecological system (Su et al. 2005; Wu et al. 2015).

\section{Economic reform and open-door policy era (1978-present)}

People's communes were disbanded in the early 1980s, together with the centralized government-planned economy. Production materials including herds, farmlands, and grasslands were gradually separated and distributed to households (Wang 2013). With the changes of the property right system, market mechanism was introduced in and gradually took dominance.

The downsizing of grassland livestock husbandry through privatization upsets the traditional way of livestock herding, causing numerous impacts on production structure and the environment. Constrained by the small and fragmented grassland size of individual owners, rotational grazing became less applicable and degradation is more possible (Zhang and Li 2008). The pastoral management system changed fundamentally; herdsmen's consciousness of grassland ownership right was motivated and began to invest on construction, especially fences. Pastoral culture of mutual support within the community began to disintegrate, while market mechanisms began to penetrate into labor force ( $\mathrm{Da}$ and Zheng 2010). As a side effect, grasslands were divided into pieces and livestock mobility was further lost (Williams et al. 2008).

In 2001, the Chinese central government initiated a national program to promote the economic development in its western regions (the "Western Development Drive"), which encouraged the flows of capital and technology from developed countries as well as China's eastern regions to its resourceful but economically less developed western regions. Industries of coal mining and electricity generation, among others, began to grow 
quickly and soon became the main driving force of economic development of Inner Mongolia. However, proper institutions of profit distribution and ecological compensation were not in place timely, resulting in soaring wealth inequality and large-scale land degradation ( $\mathrm{Da}$ and Yu 2015; Wang 2010).

Rising human and livestock populations, changing pastoral systems and grazing patterns, grassland-tofarmland conversion, and industrial activities together caused considerable damages to the grasslands of Inner Mongolia (Li et al. 2016; Su et al. 2005; Wu et al. 2015). According to the third national survey of grassland resources, about $57 \%$ of the total available grassland area in Inner Mongolia suffered moderate or more serious deterioration and desertification, with only $30-70 \%$ of natural grassland productivity (Joint Investigation Team of Grassland Ecological Research 2003). A recent study by Li et al. (2016) showed that the ecological footprint of the drylands of northern China increased from 30 million global hectares in 1990 to 170 million global hectares in 2010, with a total deficit of 100 million global hectares. Ecological problems in Inner Mongolia have had impacts on the environmental quality of surrounding regions (e.g., dust storms and reduced carbon sequestration capacities).

In order to restore the degraded grasslands, the Chinese government has enacted laws and regulations to protect the grasslands and curb land-conversion activities since the 1980s (Squires and Yang 2008a; Wu et al. 2015). Since the beginning of the new century, several large-scale national programs have been implemented, with billions of yuan invested by the government to achieve the following goals: (1) balance grassland herbage production and livestock population; (2) regulate grazing activities and restore grazing lands to natural grasslands; and (3) design proper ecological migration strategies (Da and Zheng 2010; Qi et al. 2012; Yin and Yin 2010).

\section{Changes of key environmental and socioeconomic variables \\ Ecosystem conditions}

The ecosystems of Inner Mongolia experienced continuous degradation (Fig. 4). After a series of reclaiming actives, cultivated land increased to $82,000 \mathrm{~km}^{2}$ in 1996, accounting for $9.4 \%$ of the total pastoral area (Bayaer et al. 2005a). Studies based on remote sensing showed a decreasing trend of grassland and water surface, coupled with degradation and desertification, as well as the growth of farmland and urban since 1970s to 2000s (Bayaer et al. 2005b; Shi et al. 2013). However, the deterioration trend slowed down and even reversed in some cases during the recent decades (Chen et al. 2014).

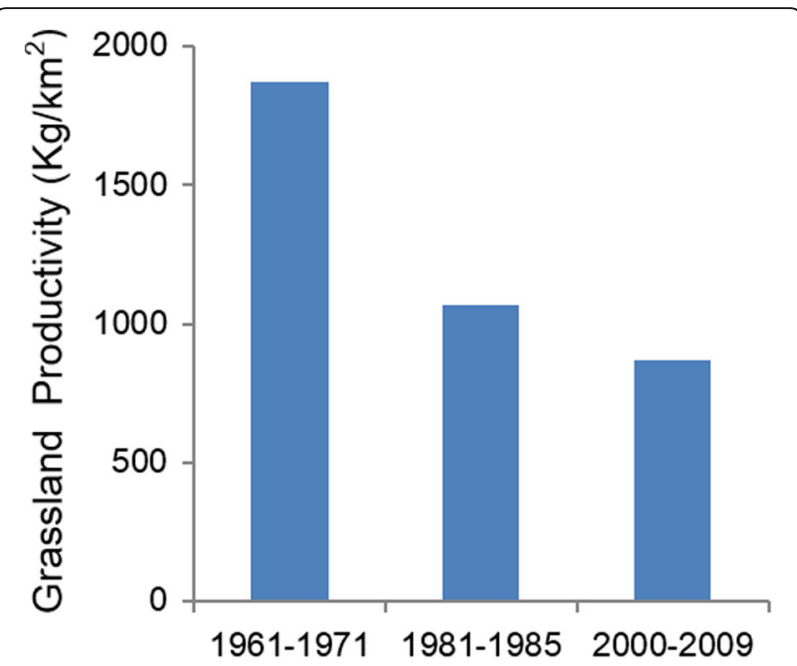

Fig. 4 Grassland productivity declining during the three periods form 1961 to 2009 (Qi et al. 2012)

\section{Population}

The total population of Inner Mongolia was 1.75 million in $2 \mathrm{AD}$, reached 2.15 million in the early nineteenth century, and increased from about six million in 1949 to 18.2 million in 1978 mainly because of immigrants from other places in China (Wu et al. 2015). Since the mid1970s, the natural population growth rate dropped rapidly and immigration rate also declined, both due largely to the implementation of family planning policy (Wang and Chog 2009) (Fig. 5). Besides, education level greatly elevated (Cui 2014; Su et al. 2002) (Fig. 6), which also shifted societal consciousness from the traditional state of seeking a livelihood to a modern state of seeking a higher living standard and self-development.

\section{Local economy}

Economy in Inner Mongolia has developed quickly with tremendous changes in its structure, especially since the reform and open-door policy in the early 1980s. Primary industry has shrunk greatly, while the secondary and

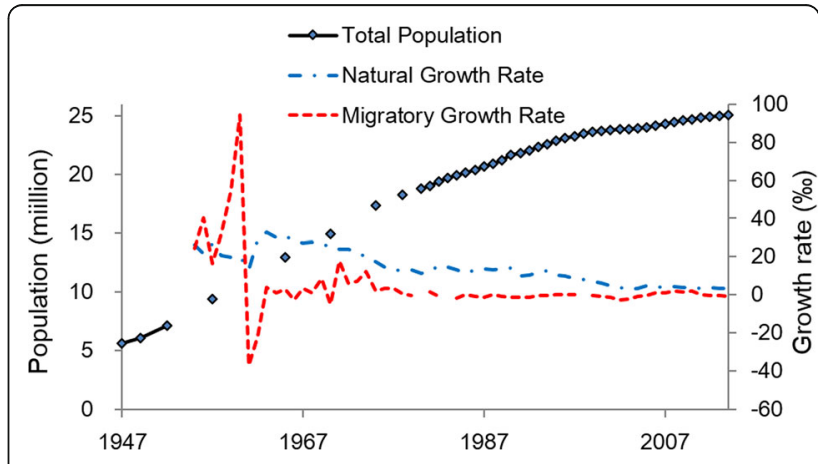

Fig. 5 Historical changes in human population and natural growth and immigration rates in Inner Mongolia. Data source: Inner Mongolia Yearbook (2015) 


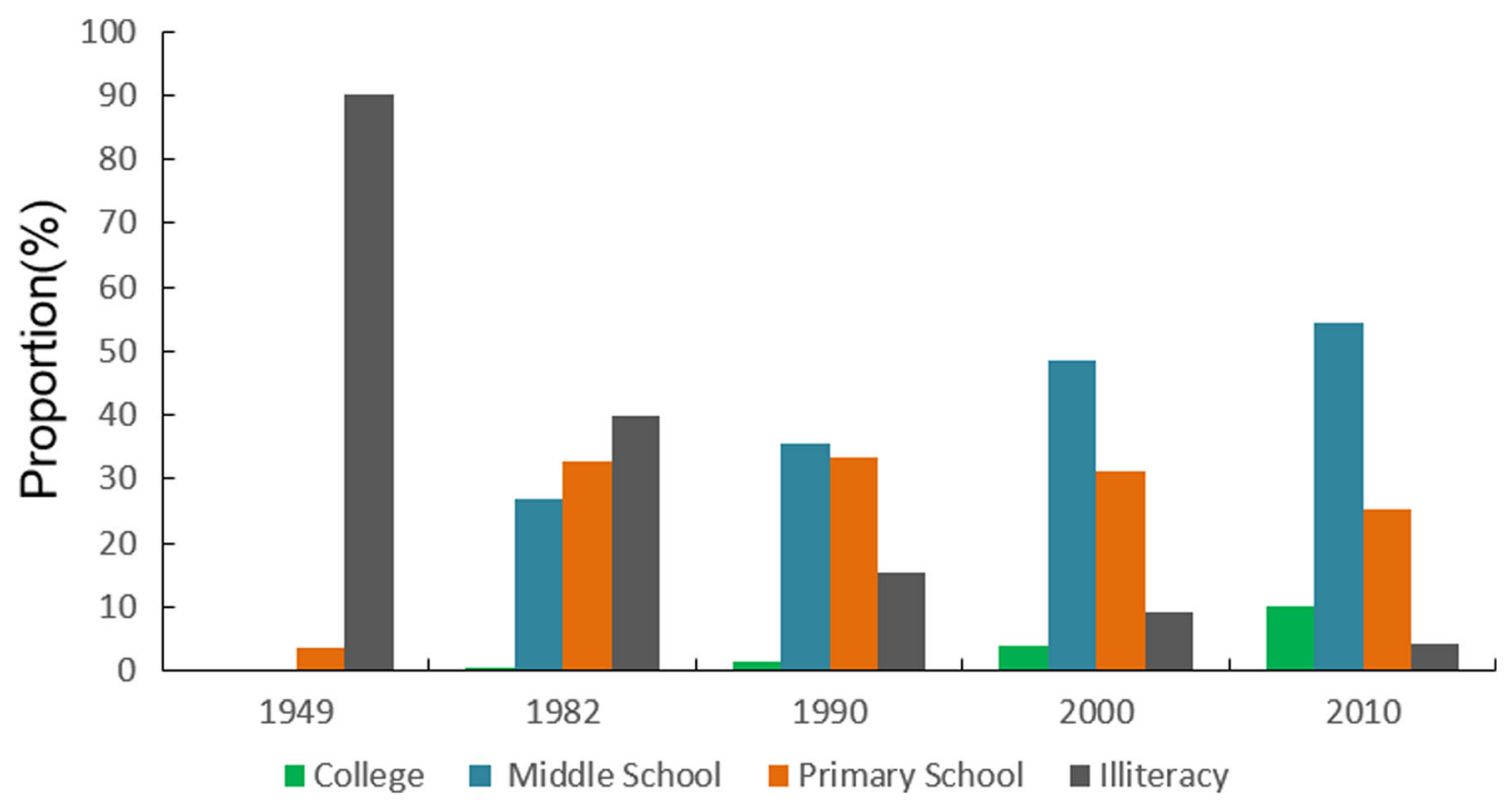

Fig. 6 Education level of Inner Mongolia. Note that the primary school of 1949 means total students at school. Data are obtained from Cui 2014; Su et al. 2002; and Inner Mongolia Yearbook (1991-2015)

tertiary industries have taken an increasingly larger share of the local economy (Chen et al. 2015a, 2015b). The grassland scenery and nomadic culture have also become key resources for tourism enterprises in the recent decades (Figs. 7 and 8).

\section{Discussion}

The past century witnessed dramatic socioeconomic and environmental transitions in Inner Mongolia. The traditional nomadic lifestyle, which maintained a fragile balance between the harsh environmental conditions and a vulnerable society, was forced to change when

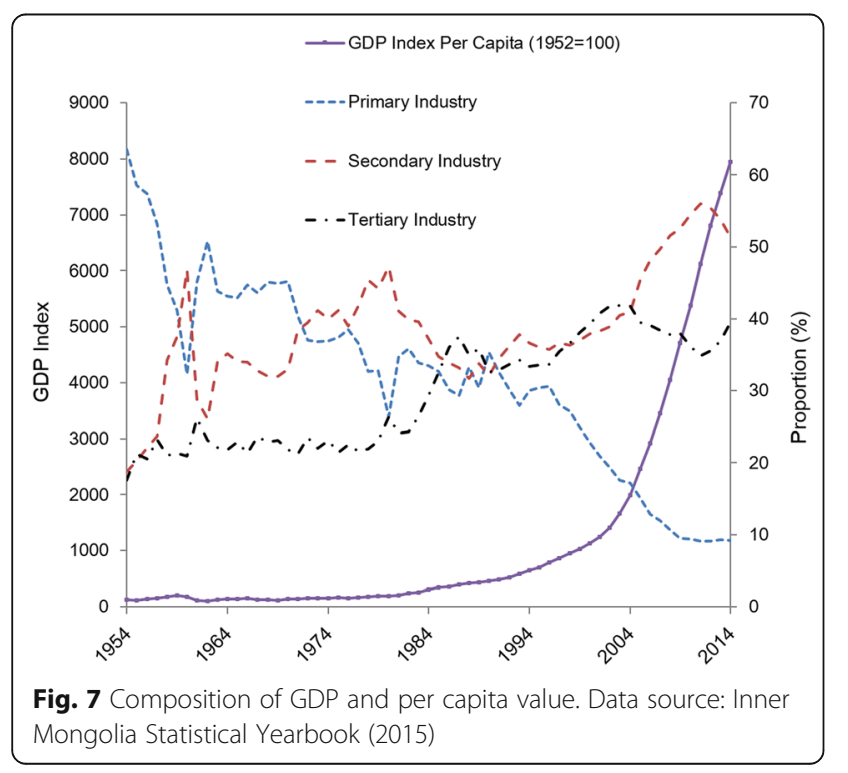

the industrial revolution spread to China. Since 1949, the People's Republic of China has initiated a process of industrialization and modernization. The economic reform and open-door policy in 1978 marked a new era of privatization and marketization in Inner Mongolia, elevating local people's aspirations for an affluent life beyond meeting the basic survival needs.

The socioeconomic development of Inner Mongolia has long depended on the natural resources in the region, which has resulted in a cascade of environmental changes. Our analysis suggests that Inner Mongolia now is faced with a development trap that may prevent it from achieving regional sustainability. The demands for mutton, beef, and cashmere from people and industries in different parts of China and the world have already exceeded the capacity of the grasslands. Intensified land use activities have profoundly transformed the landscapes of the plateau. The wide-spreading surface mining not only has torn up the face and destroyed the beauty of the grasslands but also is radically changing the identity and function of the Inner Mongolia socialecological system. While Inner Mongolia once led all other provinces of China in GDP in recent decades, its enormous economic growth dug a huge hole into its fragile environment (Wu et al. 2015), which is the primary root cause of this potential development trap.

Nevertheless, there are also reasons to believe that such traps can be overcome through institutional changes and stakeholder engagements following the principles of the place-based science of sustainability (Kates et al. 2001; Kates and Parris 2003; Wu 2013; Wu 


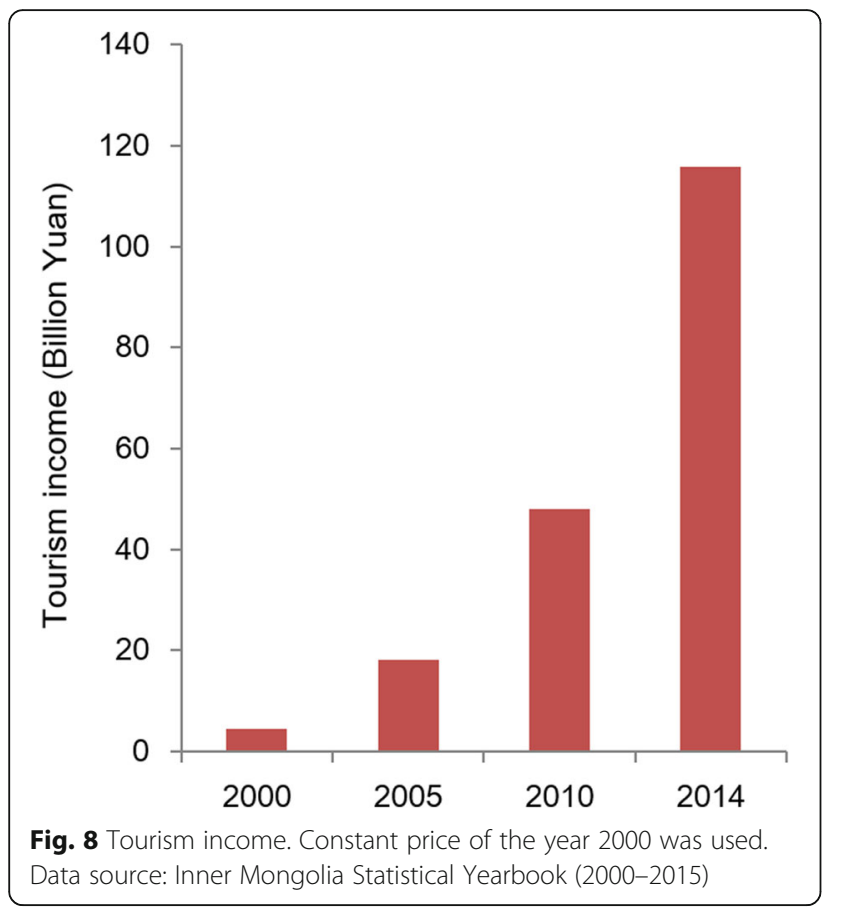

et al. 2014, 2015). There are already several encouraging signs emerging. First, the population of Inner Mongolia, as well as the population of China as a whole, seems close to reaching a steady state in the near future, so do the total demands for food, water, and other essential life-supporting materials. Second, new policies from the central government and local governments have increasingly emphasized the "quality" (environmental impacts), instead of the "quantity" (GDP), of economic development. This is particularly evident in China's 13th Five-Year Plan, approved by China's National People's Congress in March of 2016, which provides the blueprint for the economic and social development of the country from 2016 to 2020. Third, as China's socioeconomic development puts more emphasis on "quality," people's awareness and participation of protecting the environment are also increasing. These positive signs of government policy and stakeholders' attitude towards nature are essential for a sustainable future of Inner Mongolia.

To avoid the trap and achieve sustainability, however, both institutional reforms and technological innovations will be needed (Wu et al. 2015). There has been a wealth of research on the ecology, conservation, and management of the dryland systems of Inner Mongolia, which provides a valuable scientific basis for guiding the region's sustainable development in the future (Fang et al. 2015; Han et al. 2009; Kang et al. 2007; Wu and Loucks 1992). A number of suggestions have been made for making the region more environmentally sustainable, economically viable, and socially equitable (see $\mathrm{Wu}$ et al.
(2015) for a summary). Such suggestions include to develop a semi-nomadic system to increase mobility (Squires and Yang 2008b; Williams et al. 2008); to improve degraded natural grasslands and to establish artificial grasslands in appropriate locations (Hou 2015; Jia et al. 2015; Jiang et al. 2016); to establish mechanisms for forage reservation (Jia et al. 2015); and to develop an ecological pratacultural production system composed of pastures, meat, dairy and poultry production chains, bioindustry, ecological tourism, and a joint venture of grass-paturage-research-industry-commerce (Jiang et al. 2016). In addition, Wu et al. (2015) proposed a multiscale, transdisciplinary approach for future development of Inner Mongolia, guided by landscape sustainability science and land system design.

\section{Conclusions}

In this study, we examined the historical transformations of Inner Mongolia, as a coupled social-ecological system, from a traditional nomadic society to an increasingly industrialized and modernized society during the past century. Then, we discussed the challenges for achieving sustainability in this region. Inner Mongolia has made great achievements in its socioeconomic domains, but its environmental problems are mounting, possibly leading to a potential "red trap" (sensu Cumming et al. (2014)). Some additional challenges, such as climate change, were not considered here, but will likely worsen the situation (Fang et al. 2015; Qi et al. 2012; Xu et al. 2010). However, we argue that several reasons give us hope for a sustainable future. Towards this end, both research and actions are imperative. Better understanding of the coupled social-ecological system of Inner Mongolia needs to integrate biodiversity, ecosystem function, ecosystem services, and human well-being. Achieving sustainability in this region needs to maintain both ecosystem and cultural diversity and requires innovative land system design and planning directly linked to institutional changes (Wu 2013; Wu et al. 2015).

\section{Acknowledgements \\ This research is supported by the Chinese Ministry of Science and Technology through the National Basic Research Program of China (2014CB954303, 2014CB954300) and US National Science Foundation under Grant No. DEB-0618193.}

\section{Author's contributions}

Both JW and GX contributed to the conceptual framework. GX wrote the manuscript, and JW revised it. Both authors read and approved the final manuscript.

\section{Author's information}

Guanghua Xu, Assistant Professor in School of Environmental \& Resource Sciences, Zhejiang A\&F University. Interested fields include system ecology, landscape ecology, and sustainability science. Jianguo Wu, Dean's Distinguished Professor of Landscape Ecology and Sustainability Science, School of Life Sciences \& Global Institute of Sustainability. Dr. Wu's research is focused on landscape ecology, urban ecology, and sustainability science. His research combines theoretical and empirical studies that link spatial 
patterns, ecological processes, and sustainability across scales in various landscapes of China and the USA

\section{Competing interests}

The authors declare that they have no competing interests.

\section{Author details}

'School of Forestry and Bio-technology, Zhejiang A\&F University, Lin'an, Zhejiang 311300, China. ${ }^{2}$ Centre for China-Africa Agriculture and Forestry Research (CAFOR), Zhejiang A\&F University, Lin'an, Zhejiang 311300, China. ${ }^{3}$ Center for Human-Environment System Sustainability (CHESS), State Key Laboratory of Earth Surface Processes and Resource Ecology (ESPRE), Beijing Normal University, Beijing 100875, China. ${ }^{4}$ School of Life Sciences and School of Sustainability, Arizona State University, Tempe, AZ 85287, USA.

\section{Received: 11 October 2016 Accepted: 30 November 2016} Published online: 19 December 2016

\section{References}

An CR (1995) Economic development of the Japanese imperialism in Northeast China. Northeast Asia Forum 3:85-89

Bao Q (2005) On nomadic ecological economy and its enlightenment in terms of ecoligical philoshophy. Stud Dialectics Nat 21(5):8-11, Chinese

Bao Q (2015) The nomadic civilization: review of researches on its survival wisdom and ecological dimension. Inn Mongolia Soc Sci 36(1):145-153, Chinese

Barfield TJ (1989) The perilous frontier: nomadic empires and China. Basil Blackwell, Cambridge

Bayaer W, Audengaowa A, Ma A, Zhou Y, Wang J (2005a) Inner Mongolia LUCC time and space process and driving mechanism in the historic times. Hum Geogr 85:122-127. doi:10.13959/j.issn.1003-2398.2005.05.028, Chinese

Bayaer W, Shen Y, Xiao J, Audengaowa A, Tateishi R (2005b) Dynamic analysis of LUCC in Inner-Mongolia, China, by using multi-source data, vol 1-8, IGARSS 2005: IEEE International Geoscience and Remote Sensing Symposium., pp 2876-2879

Boserup E (1981) Population and technological change: a study of long-term trends. University of Chicago Press, Chicago

Caldwell J, Caldwell B, Caldwell P, McDonald P, Schindlmayr T (2006) Demographic transition theory. Springer, Dordrecht

Chapin FS, Robards MD, Huntington HP, Johnstone JE, Trainor SE, Kofinas GP et al (2006) Directional changes in ecological communities and social-ecological systems: a framework for prediction based on Alaskan examples. Am Nat 168(6):S36-S49. doi:10.1086/509047

Chappin EJL, Ligtvoet A (2014) Transition and transformation: a bibliometric analysis of two scientific networks researching socio-technical change. Renew Sust Energ Rev 30:715-723. doi:10.1016/j.rser.2013.11.013

Chen H, Shao Q, An R (2014) Spatial and temporal changes of ecosystem services values in the Inner Mongolia autonomous region from 1980s to 2005. Int J Geogr Inf Sci 16(4):582-591

Chen JQ, John R, Shao CL, Fan Y, Zhang YQ, Amarjargal A et al (2015a) Policy shifts influence the functional changes of the $\mathrm{CNH}$ systems on the Mongolian plateau. Environ Res Lett 10:1-15. doi:10.1088/1748-9326/10/8/085003

Chen JQ, John R, Zhang YQ, Shao CL, Brown GD, Batkhishig O et al (2015b) Divergences of two coupled human and natural systems on the Mongolian plateau. Bioscience 65(6):559-570. doi:10.1007/s10980-015-0261-x

Clark WC (2001) America's national interests in promoting a transition to sustainability: issues for the new US administration. Environment 43(1):18-27

Crossman ND, Burkhard B, Nedkov S, Willemen L, Petz K, Palomo I et al (2013) A blueprint for mapping and modelling ecosystem services. Ecosyst Serv 4:4-14. doi:10.1016/j.ecoser.2013.02.001

Cui N (2014) From illiteracy to literacy: a study on the literacy campaign in Inner Mongolia (1949-1959). (Master), Inner Mongolia University, Huhhot

Cumming GS, Buerkert A, Hoffmann EM, Schlecht E, von Cramon-Taubadel S, Tscharntke T (2014) Implications of agricultural transitions and urbanization for ecosystem services. Nature 515(7525):50-57. doi:10.1038/nature13945

Da L, Yu H (2015) A study of the profit distribution in the exploitation of mineral resources-using Inner Mongolia as an example. J Inn Mongolia Univ (Philos Soc Sci) 47:84-93, Chinese

Da L, Zheng Y (2010) Pastoral areas and market-a herder-based economics. Social science academic presss(China), Beijing
Fang JY, Bai YF, Wu JG (2015) Towards a better understanding of landscape patterns and ecosystems processes of the Mongolian Plateau. Landscape Ecol 30:1573-1578. doi:10.1007/s10980-015-0277-2

Farina A (2000) The cultural landscape as a model for the integration of ecology and economics. Bioscience 50(4):313-320. doi:10.1641/00063568(2000)050[0313:Tclaam]2.3.Co;2

Garmestani AS (2014) Sustainability science: accounting for nonlinear dynamics in policy and social-ecological systems. Clean Technol Envir 16(4):731-738. doi:10.1007/s10098-013-0682-7

Geels FW (2002) Technological transitions as evolutionary reconfiguration processes: a multi-level perspective and a case study. Res Policy 31:1257-1274

Geels FW (2011) The multi-level perspective on sustainability transitions: responses to seven criticisms. Environ Innov Soc Trans 1:24-40

Gell-Mann M (2010) Transformations of the twenty-first century: transitions to greater sustainability. In: Schellnhuber J, Molina M, Stern N, Huber V, Kadner S (eds) Global Sustainability: a Nobel Cause. Cambridge University Press, Cambridge, pp 1-8

Grin J, Rotmans J, Schot J, Geels F, Loorbach D (2010) Transitions to sustainable development-part 1. Routledge, Taylor \& Francis Group, New York

Han XG, Owens K, Wu XB, Wu JG, Huang JH (2009) The grasslands of Inner Mongolia: a special feature. Rangeland Ecol Manag 62(4):303-304. doi:10.2111/09-002.1

Historiography Committee of Inner Mongolia Animal Husbandry Department (2000) History of Inner Mongolia animal husbandry development. Inner Mongolia people's publishing house, Hohhot

Holling CS (1973) Resilience and stability of ecological systems. Annu Rev Ecol Syst 4:1-23

Holling CS (2001) Understanding the complexity of economic, ecological, and social systems. Ecosystems 4(5):390-405. doi:10.1007/s10021-001-0101-5

Holling CS, Meffe GK (1996) Command and control and the pathology of natural resource management. Conserv Biol 10(2):328-337. doi:10.1046/j.1523-1739. 1996.10020328.x

Hornborg A (2014) Ecological economics, Marxism, and technological progress: some explorations of the conceptual foundations of theories of ecologically unequal exchange. Ecol Econ 105:11-18. doi:10.1016/j.ecolecon.2014.05.015

Hou XY (2015) Priority and technology of grassland potential digging and efficiency adding in Inner Mongolia. Grassland Prataculture 27(3):1-3, Chinese

Hu T (2002) On the vulnerability of Chinese northern ancient nomadic economy. Soc Sci In Ningxia 5:88-93, Chinese

Jia Y (2011) Discussion on desertification and nomadism. Chin J Grassland 33(1):1-5, Chinese

Jia YS, Du S, Wang ZJ, You SH, Ge GT (2015) A review of herbage storage in pastoral areas of China. Acta Prataculturae Sinica 9:189-196. doi:10.11686/ cyxb2015177, Chinese

Jiang GM, Han XG, Wu JG (2006) Restoration and management of the Inner Mongolia grassland require a sustainable strategy. Ambio 35(5):269-270. doi:10.1579/06-S-158.1

Jiang GM, Wu GL, Cheng D, Zheng YH, Liu MZ, Li CH (2016) Characteristics and designing of eco-husbandry system: a case study in Zhenglan Banner, China. Chinese Sci Bull 61(2):224-230. doi:10.1360/N972015-00693.Chinese

Joint Investigation Team of Grassland Ecological Research (2003) It is urgent to stop sand desert and build green barrier-survey about Inner Mongolia grassland ecology and management questions. World Surv Res 3:14-18

Kang L, Han XG, Zhang ZB, Sun OJ (2007) Grassland ecosystems in China: review of current knowledge and research advancement. Philos T R Soc B 362(1482): 997-1008. doi:10.1098/rstb.2007.2029

Kates RW, Parris TM (2003) Long-term trends and a sustainability transition. Proc Natl Acad Sci U S A 100(14):8062-8067. doi:10.1073/pnas.1231331100

Kates RW, Clark WC, Corell R, Hall JM, Jaeger CC, Lowe I et al (2001) Sustainability science. Science 292(5517):641-642. doi:10.1126/science.1059386

Lattimore O (1988) Inner Asian frontiers of China. Oxford University Press, Oxford

Li B (1962) Basic types and eco-geographical principles of the zonal vegetation in Inner Mongolia. J Inn Mongolia Univ 2:42-72, Chinese

Li B (1979) Characteristics of China's grasslands. Grasslands China 1:2-12, Chinese

Li JW, Liu ZF, He CY, Tu W, Sun ZX (2016) Are the drylands in northern China sustainable? A perspective from ecological footprint dynamics from 1990 to 2010. Sci Total Environ, Epub ahead of print. doi:10.1016/j.scitotenv.2016.02.088

Lin WR, Zheng GZ (1990) History of Inner Mongolia autonomous region economy development. Inner Mongolia people's publishing house, Hohhot

Liu MY (2005) On the productivity prosperity of the nomadic production mode. Inn Mongolia Soc Sci 26(5):31-35, Chinese 
Lu S (2005) A brief comparison of ancient nomadic nationalities and agricultura nationalities. J Hubei Univ Econ 5:116-122, Chinese

Markard J, Truffer B (2008) Technological innovation systems and the multi-leve perspective: towards an integrated framework. Res Policy 37:596-615

Meadowcroft J (2011) Engaging with the politics of sustainability transitions. Environ Innov Soc Trans 1:70-75

National Research Council (1999) Our Common Journey. National Academies Press, Washington, DC

Naveh Z (2000) What is holistic landscape ecology? A conceptual introduction. Landscape Urban Plan 50(1-3):7-26. doi:10.1016/50169-2046(00)00077-3

Naveh Z (2005) Epilogue: Toward a transdisciplinary science of ecological and cultural landscape restoration. Restor Ecol 13(1):228-234. doi:10.1111/j.1526100X.2005.00028.x

Notestein F (1983) On population growth and economic development. Popul Dev Rev 9(2):345-360

Olsson P, Galaz V, Boonstra WJ (2014) Sustainability transformations: a resilience perspective. Ecol Soc 19(4):1. doi:10.5751/Es-06799-190401

Parris TM, Kates RW (2003) Characterizing and measuring sustainable development. Annu Rev Env Resour 28:559-586. doi:10.1146/annurev.energy.28.050302.10555

Qi JG, Chen JQ, Wan SQ, Ai LK (2012) Understanding the coupled natural and human systems in Dryland East Asia. Environ Res Lett 7(1):015202. doi:10.1088/1748-9326/7/1/015202

Raskin P, Banuri T, Gallopin G, Gutman P, Hammond A, Kates R et al (2002) Great transition: the promise and lure of the times ahead. Retrieved from Boston, Massachusetts

Reid W, Chen D, Goldfarb L, Hackmann H, Lee YT, Mokhele K et al (2010) Earth system science for global sustainability: grand challenges. Science 330(6006):916-917

Rotmans J, Kemp R, Asselt M (2001) More evolution than revolution: transition management in public policy. Foresight 3(1):15-31. doi:10.1108/ 14636680110803003

Scheffer M, Westley FR (2007) The evolutionary basis of rigidity: locks in cells, minds, and society. Ecol Soc 12(2):36

Scheffer M, Carpenter S, Foley JA, Folke C, Walker B (2001) Catastrophic shifts in ecosystems. Nature 413(6856):591-596. doi:10.1038/35098000

Schellnhuber HJ, Messner D, Leggewie C, Leinfelder R, Nakicenovic N, Rahmstorf S et al (2011) World in transition: a social contract for sustainability. Retrieved from Berlin, Germany

Shen B (1986) The population issue of modern Inner Mongolia. J Inn Mongolia Univ (Philos Soc Sci) 2:1-14, Chinese

Shi Y (1982) Inner Mongolia agricultural geography. Inner Mongolia People's Publishing House, Hohhot

Shi H, Zhou X, Meng F, Bai H (2013) Mongolia and Inner Mongolia LUCC regional differentiation over the past 30 years. Int J Geogr Inf Sci 5:719-725

Smith A, Vob J-P, Grin J (2010) Innovation studies and sustainability transitions: the allure of the multi-level perspective and its challenges. Res Policy 39:435-448

Squires VR, Yang YL (2008a) Historical degradation episodes in China: socioeconomic forces and their interaction with rangeland grazing systems since the 1950s. In: Squires VR, Lu XS, Lu Q, Wang T, Yang YL (eds) Rangeland Degradation and Recovery in China's Pastoral Lands. CABI, Wallingford

Squires VR, Yang YL (2008b) How can the next degradation episode be prevented? In: Squires VR, Lu XS, Lu Q, Wang T, Yang YL (eds) Rangeland Degradation and Recovery in China's Pastoral Lands. CABI, Wallingford

Steffen W, Sanderson A, Tyson P, Jager J, Matson P, Moore B et al (2005) Global change and the earth system: a planet under pressure. Springer, New York

Su L, Wu Y, Hu Y (2002) Area distributing feature of educated population in Inner Mongolia. Acta Acad Med Nei Mongol 24(3):160-163, Chinese

Su H, Liu G, He T (2005) Grassland reclamation and its harm. Grassland China 27(6):61-63, Chinese

Tian S, Ma X (2008) Review of researches on northern nomadic culture in ancient China since 1980. Western Regions Stud 2:116-124, Chinese

Tong C, Wu J, Yong S, Yang J, Yong W (2004) A landscape-scale assessment of steppe degradation in the Xilin River Basin, Inner Mongolia, China. J Arid Environ 59(1):133-149. doi:10.1016/j.jaridenv.2004.01.004

Uretogtohu (2006) The Mongolian nomadic economy and its transitions. Minzu University of China Press, Beijing

van den Bergh JCJM (2011) Environment versus growth—a criticism of "degrowth" and a plea for "a-growth". Ecol Econ 70:881-890

van den Bergh JCJM, Truffer B, Kallis G (2011) Environmental innovation and societal transitions: introduction and overview. Environ Innov Soc Trans 1:1-23

Walker B, Hollin CS, Carpenter SR, Kinzig A (2004) Resilience, adaptability and transformability in social-ecological systems. Ecol Soc 9(2):5
Wang J (2006) Ecology of agriculture and animal husbandry and traditional Mongolian society. Shandong people's publishing house, Ji'nan

Wang M (2008) The nomad's choice: the first encounter between northern nomads and imperial China: Guangxi Normal University Press

Wang G (2010) Main problems in the pastoral region economic development and their countermeasures. Inn Mongolia Soc Sci 31:114-119, Chinese

Wang X (2013) Grassland drought in the context of institution change-impacts of pastoral sedenterization, pasture segmentation and market economy. China Agric Univ J Soc Sci Ed 30:18-30, Chinese

Wang J, Chog DO (2009) Prediction of the natural population growth rate in Inner Mongolia in the next ten years. Inn Mongolia Stat 04:36-37

Weinstein MP, Turner RE, Ibanez C (2013) The global sustainability transition: it is more than changing light bulbs. Sustain: Sci Pract Policy 9:4-15

Williams A, Wang MP, Zhang MA (2008) Land tenure arrangements, property rights and institutional arrangements in the cycle of rangeland degradation and recovery. In: Squires VR, Lu XS, Lu Q, Wang T, Yang YL (eds) Rangeland degradation and recovery in China's pastoral lands. CABI, Wallingford

Wu JG (2013) Landscape sustainability science: ecosystem services and human well-being in changing landscapes. Landscape Ecol 28(6):999-1023. doi:10.1007/s10980-013-9894-9

Wu JG, Loucks OL (1992) Xilingele grassland. In: National Research Council (ed) Grasslands and Grassland Sciences in Northern China. National Academy Press, Washington, DC, pp 67-84

Wu JG, Wu T (2013) Ecological resilience as a foundation for urban design and sustainability. In: Pickett STA, Cadenasso ML, McGrath BP, Hill K (ed), Resilience in Urban Ecology and Design: Linking Theory and Practice for Sustainable Cities, Springer, Netherlands, pp. 211-230

Wu JG, Guo XC, Yang J, Qian GX, Niu JM, Liang CZ et al (2014) What is sustainability science? Chin J Appl Ecol 25(1):1-11

Wu JG, Zhang Q, Li A, Liang CZ (2015) Historical landscape dynamics of Inner Mongolia: patterns, drivers, and impacts. Landscape Ecol 30(9):1579-1598. doi:10.1007/s10980-015-0209-1

Xi T (2010) On the nomadic mode of production under the background of modernization. Forward Position 15:139-141, Chinese

Xu K (1999) Local records of Inner Mongolia animal husbandry. Inner Mongol People Publishing House, Huhhot

Xu LG, Zhou HF, Liang CA, Du L, Li H (2010) Spatial and temporal variability of annual and seasonal precipitation over the desert region of China during 1951-2005. Hydrol Process 24(20):2947-2959. doi:10.1002/hyp.7708

Yan T (2004) The Han immigrants and the modern social change in Inner Mongolia. The Ethnic Publishing House, Beijing

Yin RS, Yin GP (2010) China's primary programs of terrestrial ecosystem restoration: initiation, implementation, and challenges. Environ Manage 45(3):429-441. doi:10.1007/s00267-009-9373-x

Zeder MA (2008) Domestication and early agriculture in the Mediterranean Basin: origins, diffusion, and impact. Proc Natl Acad Sci U S A 105(33):11597-11604. doi:10.1073/pnas.0801317105

Zhang Q, Li W (2008) Distributed overgrazing: a neglected cause of grassland degradation in Inner Mongolia. J Arid Land Resour Environ 12:8-15, Chinese

\section{Submit your manuscript to a SpringerOpen ${ }^{\circ}$ journal and benefit from:}

- Convenient online submission

- Rigorous peer review

- Immediate publication on acceptance

- Open access: articles freely available online

- High visibility within the field

- Retaining the copyright to your article

Submit your next manuscript at springeropen.com 